\title{
PENYULUHAN TENTANG BAHAYA NARKOBA PADA REMAJA MELALUI PENDEKATAN EDUKASI AFEKTIF
}

\section{EXTENSION PROGRAM ABOUT THE DANGERS OF DRUGS FOR YOUTH THROUGH AFFECTIVE EDUCATION APPROACH}

\author{
Oleh: \\ Yuliati, Rasianna Br. Saragih, Yudisiani Jurusan Ilmu \\ Komunikasi FISIP Universitas Bengkulu Email: \\ ali_bengkulu08@yahoo.com
}

\begin{abstract}
Community service activities has a title "Guidance the Dangers of Drug for Teenager through Affective Education Approach". The target of the community activities program are youth / high school students (SMA) 1 Talang Empat, Central Bengkulu Regency, Bengkulu Province. Activities carried out in SMA-N 1 Central Bengkulu aims to encourage young people, in this case school students to stay away from the dangers of drugs. Counseling methods with affective educational approach is deemed appropriate to be used for this approach is not only limited to providing information about the dangers of drugs alone but students are also stimulated to think about the values of life of their own and make a conclusion about whether the benefits of drug abuse in life. Affective aspects of education aimed at developing the personality, maturation itself, increase the ability in decisions making, knowing how to cope with the mental stress effectively. Students have a tendency to not want to get involved in drug abuse. In addition caused enough understanding that drugs only bring harm health and spend a lot of money, students also tend to choose friends who have the same background (students).
\end{abstract}

Keywords: drugs, affective education, youth

\section{PENDAHULUAN}

Peredaran dan penyalahgunaan narkoba di Indonesia terus mengalami peningkatan. Setiap tahun jumlah kasus penyalahgunaan dan korban terus bertambah. Upaya Badan Narkotika Nasional (BNN) dalam mengkampanyekan bahaya penyalahgunaan narkoba belum mampu memberikan hasil yang memuaskan. Ditengarai masih banyak orang yang setelah melakukan rehabilitasi (penyembuhan) akhirnya kembali terjerumus dalam penyalahgunaan narkoba. Hal yang memprihatinkan adalah banyaknya generasi muda (remaja) yang ikut terjerumus menjadi pelaku sekaligus korban penyalahgunaan narkoba.

Data dari Badan Narkotika Nasional menunjukkan bahwa $20 \%$ pengguna narkoba adalah remaja, yang kebanyakan masih aktif sekolah, baik di tingkat SLTP, SLTA, maupun di Perguruan Tinggi. Ditemukan pula kenyataan bahwa ada di antara pengguna yang masih 
duduk di bangku Sekolah Dasar. Sementara itu, data dari BNN Provinsi Bengkulu menunjukkan bahwa dari tahun 2011 hingga tahun 2013, tersangka kasus narkoba berdasarkan jenjang umur, setiap tahun mengalami peningkatan. Tersangka usia 16 - 19 tahun pada tahun 2010 sebanyak 15 kasus, 2011 sebanyak 28 kasus, tahun 2012 sebanyak 31 kasus, dan tahun 2013 sebanyak 50 kasus (sumber: BNN Provinsi Bengkulu tahun 2014).

Berangkat dari uraian tersebut di atas, sosialisasi tentang bahaya narkoba merupakan hal yang penting untuk dilakukan, terutama pada remaja, dalam hal ini siswa-siswa sekolah, yang dipandang juga dapat menjadi agen of change. Pengetahuan yang didapat oleh siswa diharapkan dapat memperkuat siswa untuk dengan tegas menolak penggunaan narkotika dan obat-obat berbahya. Di samping itu, dengan pengetahuan yang benar tentang bahaya narkoba, remaja dapat berbagi pengetahuan dengan kawan-kawannya untuk tidak mendekati zat-zat yang berbahaya tersebut. Hal ini dipandang sebagai upaya yang efektif, sebab pada umumnya remaja lebih suka mendengar dan mencontoh perilaku kawan-kawannya. Sebagai sosok yang sedang mencari identitas diri, para remaja sering merujuk kawan-kawannya sebagai model. Disamping itu, rasa ingin tahu yang besar sering mendorong remaja untuk mencoba hal-hal yang tampak menarik, sehingga para remaja rentan terjerumus pada hal-hal negatif, termasuk pada penggunaan obat-obat terlarang.

Pendekatan Edukasi Afektif merupakan pendekatan penyuluhan yang ditujukan pada pengembangan interpersonal dan sosial dari remaja. Pendekatan edukasi afektif ini bertujuan meningkatkan: 1) Pengertian mengenai diri sendiri dan menerimanya melalui kegiatan konseling. 2) Kemampuan keterampilan hidup dan interpersonal (life interpersonal skill).

Penyuluhan dengan pendekatan edukasi afektif ini berupa penyampaian informasi yang tepat terpercaya, objektif, jelas dan mudah dimengerti tentang narkoba dan pengaruhnya bagi tubuh dan perilaku manusia, dan mengkaitkannya dengan pendidikan kesehatan secara luas dan pendidikan tentang menghadapi masalah hidup. Melalui pemahaman tentang nilai-nilai kehidupan, siswa akan dirangsang untuk memikirkan nilainilai kehidupannya sendiri dan membuat kesimpulan tentang manfaat tidaknya penyalahgunaan narkoba dalam kehidupan. Aspek edukasi afektif bertujuan mengembangkan kepribadian, pendewasaan diri, peningkatan kemampuan membuat keputusan, mengetahui cara mengatasi tekanan mental secara efektif, peningkatan kepercayaan diri, dan meningkatkan kemampuan komunikasi (Assegaf, 1987:51-52).

\section{METODE PENGABDIAN}

\section{Pemecahan masalah}

Berdasarkan data dari Badan Narkotika Nasional (BNN) Provinsi Bengkulu, jumlah tersangka kasus penyalahgunaan narkoba dari tahun 2010 hingga 2013 mengalami peningkatan terutama dikalangan pelajar/siswa. Hal tersebut tentu sangat memprihatinkan karena siswa seharusnya terhindar dari masalah-masalah tersebut akan tetapi mereka malah terjerumus menggunakan narkoba. Untuk itu, siswa perlu diberi pengetahuan dan 
pemahaman tentang bahaya dan dampak penyalahgunaan narkoba agar mereka yang belum atau pun yang sudah menggunakan bisa mengetahui dampak penggunaan narkoba.

Metode penyuluhan dengan pendekatan edukasi afektif dipandang tepat untuk digunakan karena pendekatan ini tidak hanya sebatas memberikan informasi tetapi khalayak sasaran juga dirangsang untuk memikirkan nilai-nilai kehidupannya sendiri dan membuat kesimpulan tentang materi penyuluhan (Ban and Hawkins, 1999). Aspek edukasi afektif bertujuan mengembangkan kepribadian, pendewasaan diri, peningkatan kemampuan membuat keputusan, mengetahui cara mengatasi tekanan mental secara efektif.

\section{Khalayak Sasaran}

Target dari program pelaksanaan kegiatan pengabdian ini adalah para remaja/siswa SMA-N 1 Talang Empat, Kabupaten Bengkulu Tengah, Provinsi Bengkulu. Dari data yang diperoleh, bahwa $22 \%$ pengguna narkoba adalah remaja. Beranjak dari data tersebut, maka dipandang perlu untuk memberikan penyuluhan kepada remaja dalam hal ini siswa agar siswa mampu menolak narkoba dan memilih untuk berkegiatan secara sehat.

Kegiatan penyuluhan ini dilaksanakan di SMA Negeri 1 Talang Empat Kabupaten Bengkulu Tengah. Sasaran dalam penyuluhan ini adalah para remaja dalam hal ini siswa SMA Negeri 1 Talang Empat. Seperti yang telah disampaikan bahwa remaja merupakan sasaran strategis bagi pengedar narkoba sehingga fenomena tersebut dianggap penting untuk memberikan pemahaman, pengetahuan, dan keterampilan bagi remaja mengenai apa itu narkoba, dampak penyalahgunaan narkoba dan keterampilan apa yang bisa dimiliki remaja dalam menangkal pengaruh buruk narkoba.

\section{Pendekatan}

\section{Kondisi awal}

1. Kurangnya pengetahuan remaja tentang narkoba dan dampak penyalahgunaan narkoba.

2. Remaja mempunyai rasa ingin tahu yang besar akan sesuatu, sehingga kurangnya pengetahuan bisa membuat remaja terpengaruh menggunakan narkoba.

3. Kecenderungan remaja untuk menjadikan kawan sebaya sebagai rujukan perilaku.

\section{Intervensi}

1. Memberikan penyuluhan berupa pengetahuan tentang narkoba.

2. Menumbuhkan kesadaran para siswa mengenai dampak penyalahgunaan narkoba.

3. Mempersuasi siswa agar tidak terpengaruh menggunakan narkoba dan memberikan pemahaman tentang cara menghindarkan diri dari pengaruh buruk narkoba. 


\section{Tujuan}

Melalui kegiatan penyuluhan ini, diharapkan siswa memperoleh pengetahuan, pemahaman, dan kesadaran akan bahaya narkoba serta dampak penyalahgunaannya. Siswa bisa terhindar dari pengaruh buruk narkoba.

\section{Kondisi yang diharapkan}

Para siswa yang menjadi sasaran kegiatan ini tidak terpengaruh menggunakan narkoba. Para siswa bisa berprestasi di segala aspek dengan tidak menggunakan narkoba. Siswa sebaiknya menyibukkan diri untuk kegiatan-kegiatan yang positif sehingga tidak ada kesempatan untuk memikirkan hal-hal yang merugikan termasuk narkoba.

\section{Keterkaitan}

Kegiatan pengabdian ini diharapkan memberikan manfaat terutama bagi para siswa. Setelah mereka mendapatkan penyuluhan mereka memiliki pengetahuan tentang bahaya narkoba dan dampak penyalahgunaan narkoba. Siswa juga dirangsang untuk memikirkan nilai-nilai kehidupannya sendiri dan mengetahui tentang manfaat tidaknya penyalahgunaan narkoba dalam kehidupan. Melalui penyuluhan ini siswa diharapkan dapat mengembangkan kepribadiannya, pendewasaan diri, memiliki kemampuan dalam membuat keputusan, mampu mengatasi tekanan-tekanan yang merugikan.

Sementara bagi pengusul kegiatan, kegiatan ini dapat mengembangkan kerjasama antar lembaga, sebagai aplikasi ilmu komunikasi dimasyarakat terutama sekali untuk mempersuasi remaja dalam hal ini siswa agar memiliki pengetahuan tentang bahaya narkoba dan dampak penyalahgunaannya.

\section{Evaluasi}

Evaluasi dibutuhkan untuk mengetahui tingkat keberhasilan dari suatu kegiatan. Dalam kegiatan ini evaluasi yang ditetapkan meliputi:

1. Pengetahuan siswa mengenai bahaya narkoba dan dampak penyalahgunaan narkoba. Dengan penyuluhan yang diberikan, para peserta dalam hal ini siswa bertambah pengetahuannya tentang bahaya dan dampak penyalahgunaan narkoba.

2. Siswa tidak ada yang terjerumus menggunakan narkoba.

Bentuk evaluasi yang dilakukan oleh pelaksana kegiatan adalah dengan melakukan monitoring kepada peserta kegiatan setelah kegiatan selesai dilakukan. Hal ini dipandang penting untuk memastikan apakah ada action yakni siswa tidak menggunakan narkoba.

\section{HASIL DAN PEMBAHASAN}

\section{Pelaksanaan Kegiatan}

Pelaksanaan kegiatan penyuluhan sesuai dengan kesepakatan jadwal yang telah ditentukan, yakni pada hari Sabtu, 6 September 2014, pukul 10.00 WIB, bertempat di aula 
SMA Negeri 1 Talang Empat Bengkulu Tengah. Kegiatan ini diikuti oleh 50 orang siswa kelas 10 selama \pm dua jam.

Pada sesi pertama, Ibu Rolena dari BNN memberikan penjelasan mengenai materi penyuluhan, meliputi: apa yang dimaksud dengan narkoba, jenis-jenis narkoba, dampak penyalahgunaan narkoba, dan juga gambar-gambar yang menunjukkan rusaknya kesehatan (tubuh) pengguna narkoba.

Sesi ke-dua diadakan tanya-jawab dan diskusi. Pada awalnya siswa tampak malu dan ragu untuk bertanya. Kehadiran beberapa guru yang juga antusias dalam mengikuti kegiatan ini mendorong keberanian siswa untuk bertanya.

Salah satu pertanyaan yang menarik adalah: mengapa rokok yang menjadi pintu masuknya narkoba (ganja, narkotik) tidak dilarang peredarannya. Hal ini menjadi satu ironi, sebab pada umumnya orang mengenal narkoba melalui rokok. Setelah tergantung (kecanduan), barulah orang akan mencari zat yang efeknya lebih kuat, yakni dalam bentuk obat-obatan (misal: inex, ecstasi).

Adapun materi penyuluhan (BNN Provinsi Bengkulu, 2014) sebagai berikut:

1. Pemahaman tentang narkoba

Pengertian Narkotika

menurut UU NO 35 thn 2009 ttg Narkotika

Narkotika adalah zat atau obat yg berasal dari tanaman atau bukan tanaman,baik sintetis maupun semisintetis ,yg dpt menyebabkan penurunan atau perubahan kesadaran,hilangnya rasa, mengurangi sampai menghilangkan rasa nyeri,

dan dpt menimbulkan ketergantungan

\section{Apa Itu Narkoba?}

Adalah bahan/zat aktif yang mempengaruhi kondisi kejiwaan/psikologis seseorang (pikiran, perasaan dan perilakunya) serta dapat menimbulkan ketergantungan secara fisik maupun psikologis

Jenis Narkoba

\begin{tabular}{|l|l|l|}
\hline NARKOTIKA & $\begin{array}{l}\text {-MORFIN } \\
\text { - HEROIN } \\
\text { - KOKAIN } \\
\text { - GANJA } \\
\text {-SHABU } \\
\text { - EKSTASI } \\
\text { - ATS }\end{array}$ \\
\hline PSIKOTROPIKA & $\begin{array}{l}\text {-ALKOHOL } \\
\text { - NIKOTIN } \\
\text {-KECUBUNG } \\
\text {-MAGICMASROM } \\
\text { - LEM }\end{array}$ \\
\hline
\end{tabular}


Pemahaman terhadap bahaya ketergantungan ini perlu diberikan kepada siswa untuk menunjukkan bahwa tindakan coba-coba adalah tindakan berbahaya. Pada umumnya siswa menganggap bahwa tindakan coba-coba dapat ditolerir, sebab hanya mengkonsumsi dalam jumlah sedikit dan berniat hanya dilakukan sekali saja. Hal yang tidak dipahami oleh siswa adalah, masuknya zat-zat yang dapat menyebabkan penurunan kesadaran dan menghilangkan rasa sakit atau nyeri, sehingga yang dirasakan tubuh adalah perasaan nyaman. Hal inilah yang kemudian menyebabkan pengguna ingin mencoba dan mencoba lagi, hingga akhirnya tidak dapat melepaskan diri.

2. Penggolongan Narkotika

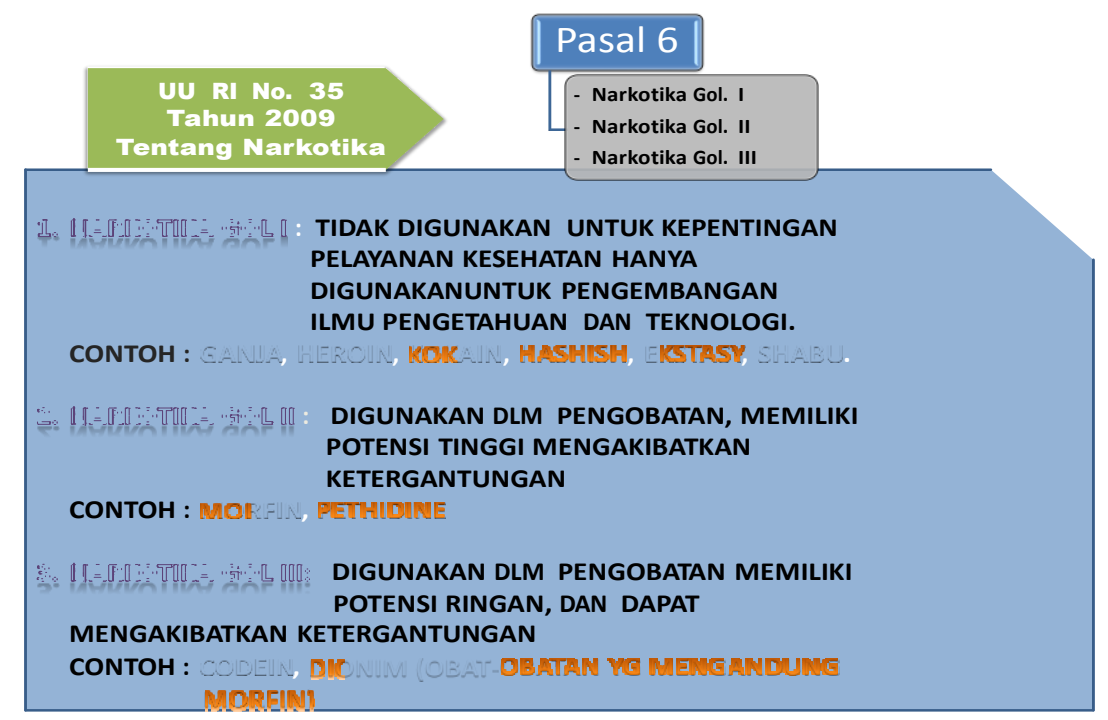

Pengetahuan ini diberikan kepada siswa dengan maksud, memberikan penjelasan bahwa keberadaan narkotika sesungguhnya lebih diperuntukkan bagi keperluan ilmu pengetahuan dan teknologi. Selain itu narkotika juga sebagai bahan obat-obatan di bawah pengawasan dokter, sehingga bahan-bahan narkotika tidak boleh disalahgunakan untuk keperluan di luar maksud tersebut.

3. Kelompok yang rawan dalam penyalahgunaan narkoba

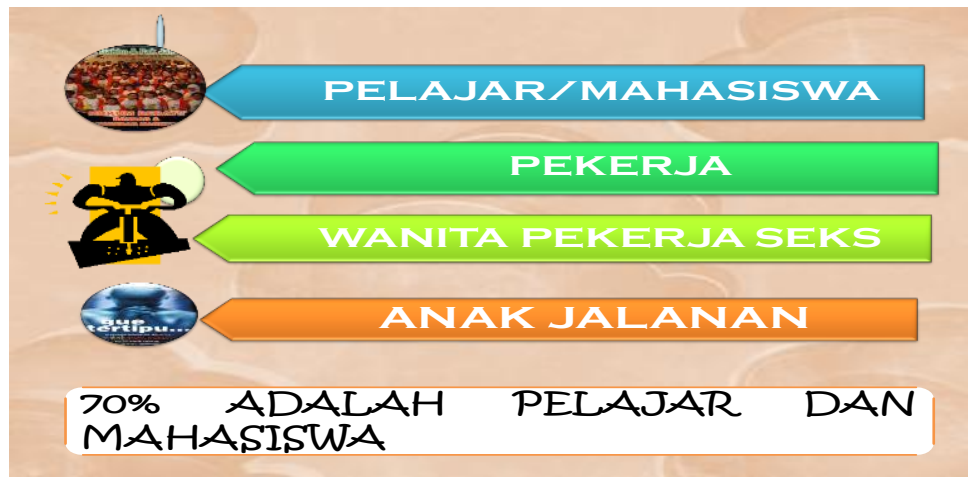




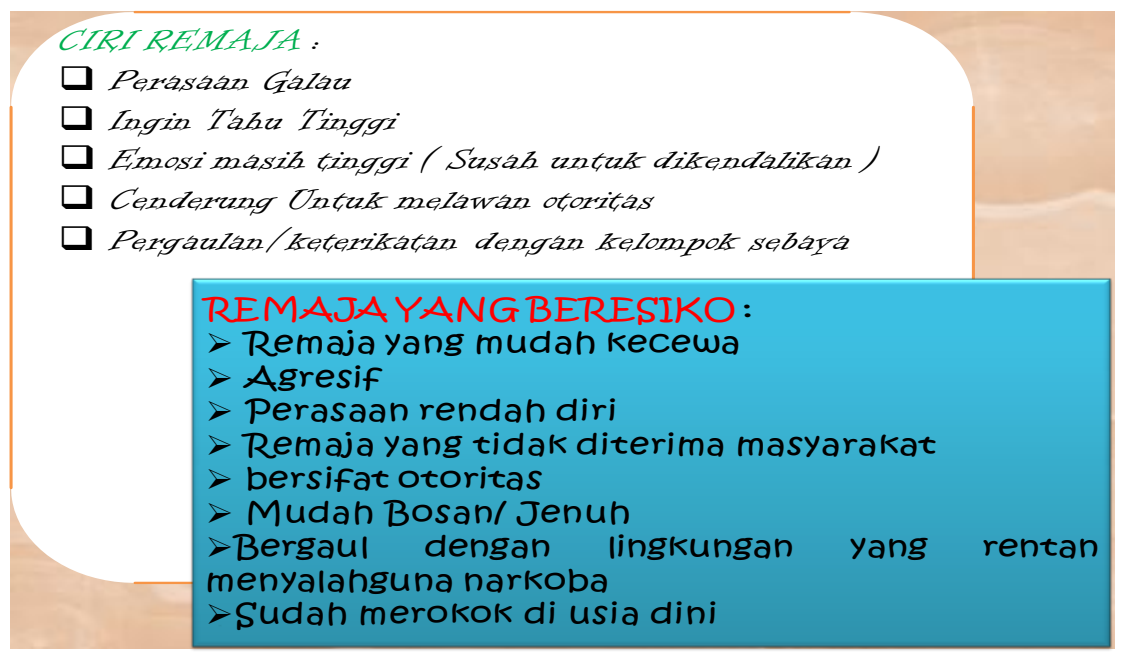

Remaja adalah kelompok usia peralihan dari masa kanak-kanak ke masa dewasa. Pada masa ini remaja sedang mencari jati diri dan cenderung mengidentifikasikan diri dengan kelompoknya (peer group). Oleh karenanya, lingkungan sebaya, keluarga, dan sekolah menjadi faktor penting dalam memperkuat pribadi remaja, terutama siswa dalam pergaulan yang baik.

Sifat labil siswa dapat dimanfaatkan oleh pihak-pihak tak bertanggung-jawab (pengedar narkoba) untuk memancing rasa ingin tahu pada hal-hal baru seperti narkoba, dan perasaan hebat apabila berani memakainya. Hal inilah harus menjadi perhatian semua pihak, yakni untuk selalu memberikan dan menciptakan lingkungan yang baik, sehingga siswa dapat mengembangkan kepribadiannya menjadi individu yang kuat.

4. Efek penyalahgunaan narkoba.

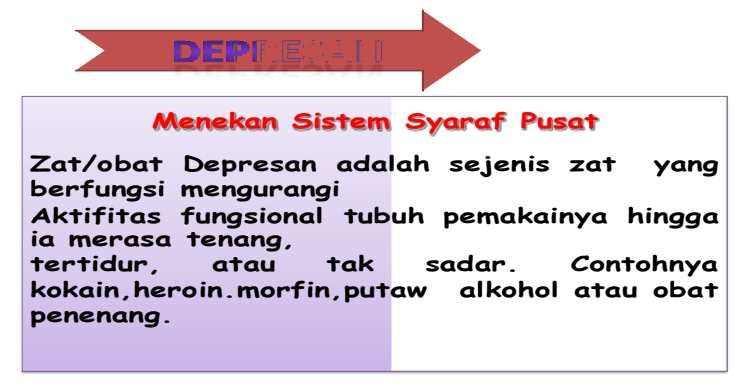

Materi berikutnya yang menjadi bahasan adalah dampak atau efek penyalahgunaan narkoba. Efek narkoba dapat berupa depresan, yang menyebabkan pemakai merasa tubuhnya menjadi tenang, tidur sampai tak sadar. Hal ini biasanya akan membuat pengguna merasa nyaman dan terbebas dari masalah sehari-hari. Bagi siswa yang labil, hal ini sering dianggap 
sebagai solusi untuk melupakan masalahnya; sehingga timbul keinginan untuk terus menerus dalam kondisi ini.

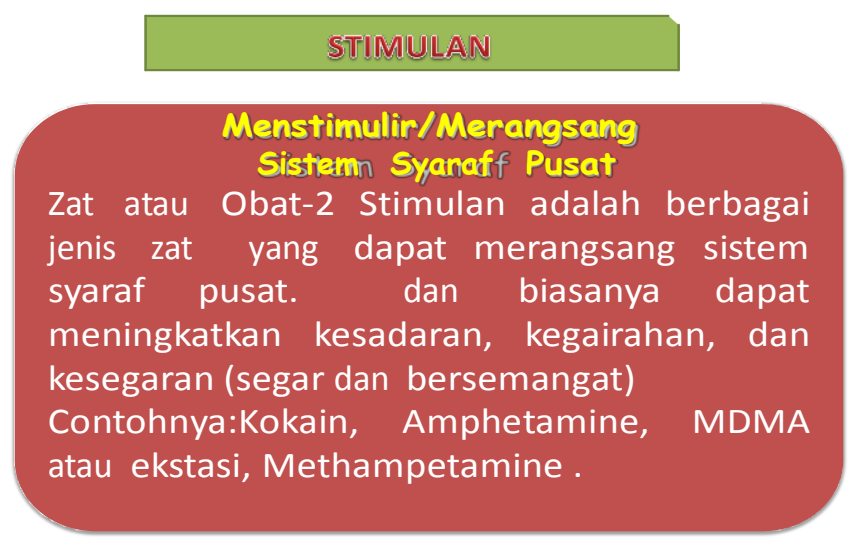

Dampak lain dari narkoba adalah sebagai stimulan, yakni merangsang sistem syaraf pusat. Pengguna biasanya akan merasa sangat bersemangat dan muncul keberanian. Serta tidak mudah lelah. Kondisi ini banyak diinginkan terutama oleh mereka yang memiliki kecenderungan sebagai orang yang tertutup dan pemalu. Efek obat ini sering menjadi alasan mereka untuk mengkonsumsinya, agar dapat tampil lebih percaya diri.

\section{HALUE UI U}

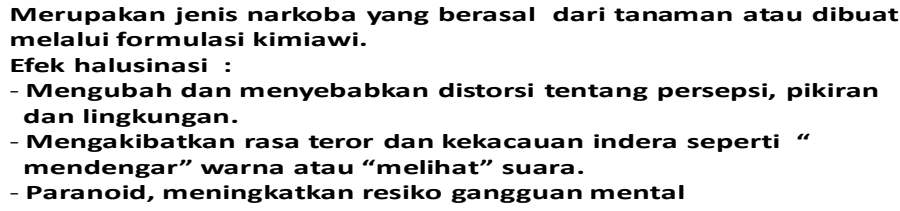

Efek halusinogen akan menyebabkan pengguna mengalami gangguan berpikir dan munculnya rasa takut yang berlebihan. Pada kondisi parah akan menyebabkan gangguan mental, muncul rasa curiga berlebihan dan tidak ingin bergaul.

Tembakau mengandung

nikotin, tar dan carbon

monoksida yang berbahaya

serta zat lain, seluruhnya tak

kurang dari 4,000 bahan kimia

dan sebanyak 43 di antaranya

bersifat karsinogenik.

Menyebabkan kanker paru,

penyempitan pembuluh darah,

prnyakit jantung, tekanan

darah tinggi.

2-tetes nikotin murni dapat

membewalh orang secara instan 
Salah satu pertanyaan yang diajukan siswa dalam diskusi adalah mengenai rokok. Pertanyaan ini mewakili pikiran kebnyakan siswa dan guru-guru. Mengapa rokok tetap dijual bebas, padahal masuknya narkoba seringkali dan paling mudah adalah melalui rokok. Dalam hal ini kebijakan pemerintah juga menjadi pertanya semua peserta.

Efek tembakau sudah dijelaskan, dan bahkan ditulis di bungkus rokok itu sendiri, dapat membahayakan bagi perokok aktif maupun pasif. Namun demikian kenyataan menunjukkan bahwa rokok tetap mudah dicari dan dijual di berbagai tempat.

\section{PROSES TERBENTUKNYA KETERGANTUNGAN NARKOBA}

1. Kompromi
\begin{tabular}{|l|}
\hline Sikap menentang narkoba tidak tegas, Mau \\
bergaul dengan pemakai narkoba
\end{tabular}
\begin{tabular}{|l|l|}
\hline 2. Coba-coba & $\begin{array}{l}\text { Segan menolak tawaran. Ikut-ikutan memakai } \\
\text { narkoba untuk mencoba }\end{array}$ \\
\hline 3. Toleransi & $\begin{array}{l}\text { Sesudah memakai beberapa kali, tubuh menjadi } \\
\text { toleran, perlu penambahan dosis yang lebih } \\
\text { besar agar mendapatkan efek yang dikehendaki }\end{array}$ \\
\hline
\end{tabular}

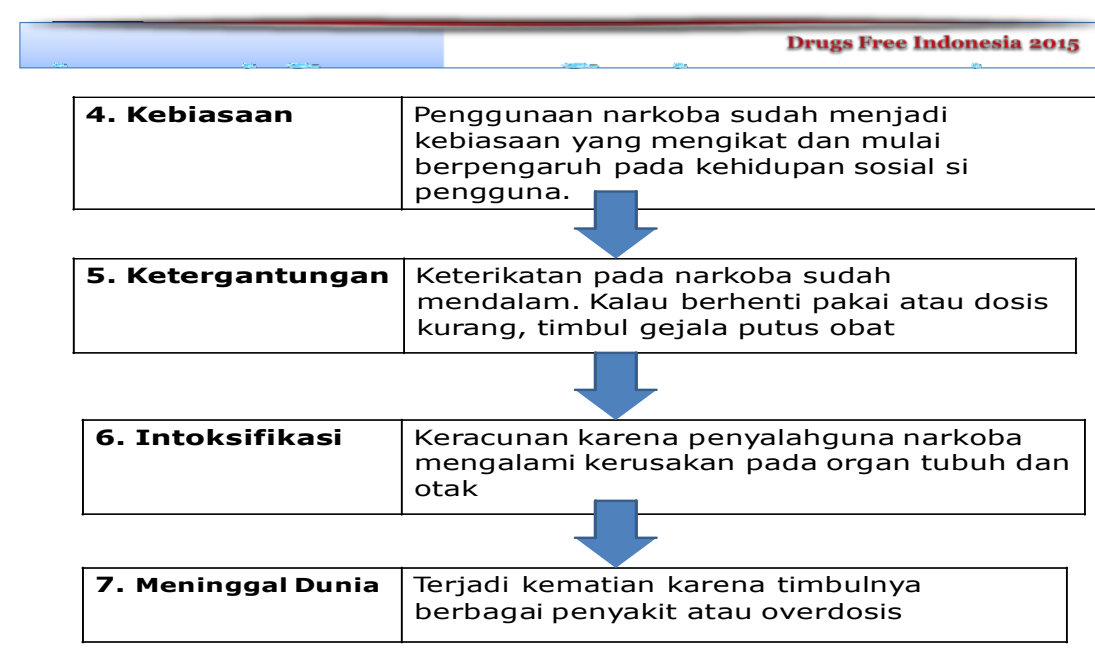

\section{Evaluasi}

Penyuluhan ini lebih ditekankan pada ranah afektif siswa, yakni sikap siswa terhadap narkoba. Penambahan pengetahuan pada ranah kogmitif pada umumnya tidak banyak menemui kesulitan, karena materi disajikan dengan jelas. Namun seringkali pengetahuan tidak selalu diiringi dengan sikap dan perbuatan. Bagi siswa, untuk berani menentukan sikap, apalagi siap yang berbeda dengan lingkungan, dengan kawan sebaya atau kawan yang lebih 
tua dan biasa dijadikan model (panutan) memerlukan keberanian dan tekad yareng kuat. Oleh karenanya penyuluhan ini bertujuan untuk membangun kepribadian kuat dan kemandirian siswa dalam mengambil keputusan dalam bersikap.

Dari hasil diskusi dapat disimpulkan bahwa siswa memiliki kecenderungan untuk tidak ingin terlibat pada penyalahgunaan narkoba. Selain disebabkan pemahaman yang cukup bahwa narkoba hanya membawa kerugian kesehatan dan menghabiskan banyak uang, siswa juga cenderung memilih teman-teman yang memiliki latar belakang yang sama, yakni para pelajar. Mereka juga sudah memiliki informasi mengenai beredarnya narkoba dalam bentuk makanan / permen yang dapat membius dan menyebabkan ketagihan. Mereka menyatakan bahwa mereka berhati-hati terhadap hal-hal yang dtawarkan oleh orang tak dikenal.

\section{KESIMPULAN}

Pemahaman mengenai bahan-bahan dan bentuk-bentuk kemasan narkoba serta proses dan dampak dari penyalahgunaan narkoba belum banyak dikenal oleh para siswa. Para siswa pada umumnya tidak berhubungan dengan pengedar yang merupakan orang asing (tak dikenal). Para siswa menyadari adanya kaitan erat antara perokok dengan kemungkinan penyalahgunaan narkoba melalui rokok. Para siswa cenderung untuk tidak mencoba-coba narkoba.

Siswa memiliki kecenderungan untuk tidak ingin terlibat pada penyalahgunaan narkoba. Selain disebabkan pemahaman yang cukup bahwa narkoba hanya membawa kerugian kesehatan dan menghabiskan banyak uang, siswa juga cenderung memilih temanteman yang memiliki latar belakang yang sama, yakni para pelajar. Mereka juga sudah memiliki informasi mengenai beredarnya narkoba dalam bentuk makanan/permen yang dapat membius dan menyebabkan ketagihan. Mereka menyatakan bahwa mereka berhatihati terhadap hal-hal yang dtawarkan oleh orang tak dikenal.

\section{DAFTAR PUSTAKA}

Assegaf, 2014, Pengertian Penyuluhan http://netisulistiani.wordpress.com/penyuluhan/ penyuluhan-narkoba/ diakses 15 April 2014.

Ban, Van Den dan Hawkins, 1999, Penyuluhan Pertanian, Agnes Dwina Herdiastuti (Pent).

Judul Asli: Agricultural Extention (Second Edition), Kanisius, Yogyakarta.

Badan Narkotika Nasional Provinsi Bengkulu, 2014, Bengkulu. 